\title{
PEMANFAATAN TUMBUHAN OBAT UNTUK MENGATASI GANGGUAN SISTEM PENCERNAAN OLEH SUKU DAYAK IBAN: STUDI KASUS DI KABUPATEN KAPUAS HULU, KALIMANTAN BARAT
}

\section{UTILIZATION OF MEDICINAL PLANTS TO TREAT DIGESTIVE SYSTEM DISORDERS BY DAYAK IBAN TRIBE: CASE STUDY IN KAPUAS HULU REGENCY, WEST KALIMANTAN}

\author{
Fathul Yusro $^{\left.1^{*}\right)}$, Yeni Mariani ${ }^{1)}$, Evy Wardenaar ${ }^{1)}$, \\ Fakultas Kehutanan Universitas Tanjungpura, Pontianak \\ *email: fathulyusro@gmail.com
}

\begin{abstract}
Penelitian ini bertujuan untuk menganalisis pola pemanfaatan tumbuhan obat suku Dayak Iban di Kabupaten Kapuas Hulu Kalimantan Barat untuk mengatasi gangguan sistem pencernaan. Metode penelitian yang digunakan adalah purposive sampling dengan teknik wawancara semi terstruktur dengan target $100 \%$ responden KK. Lokasi penelitian adalah desa Lanjak Besar (dusun Tekalong dan Bejabang) dan Desa Sepandan (dusun Tematu 1 dan Tematu 3). Analisis data berupa pola pemanfaatan tanaman (Use value/UV, Informant concensus factor/ICF dan fidelity level/FL), dan hubungan antara karakteristik responden dan level pengetahuan tumbuhan obat (chi square test). Sebanyak 21 species tanaman obat digunakan oleh $60 \%$ responden untuk mengatasi masalah pencernaan. Jenis-jenis tanaman yang memiliki nilai penggunaan (UV) yang tinggi adalah bawang merah $(0,53)$, pisang $(0,5)$ dan jambu batu $(0,44)$. Nilai tertinggi dari ICF antara lain untuk mengobati maag $(1,00)$, sariawan $(1,00)$, pencahar $(1,00)$, susah buang air besar $(9,98)$, dan masuk angin $(0,98)$. Jenis-jenis tanaman yang memiliki nilai fidelity level (FL) tertinggi (100) adalah salam (diare), langsat (flatulence), leban (maag), jeruk sambal (sariawan), durian (sakit lidah), pisang dan papaya (susah buang air besar), sahang putih, sugan dan rumput cupak (sakit perut), bawang merah (masuk angin), putri malu (sakit gigi), japa dan bawang lembak (ambein/wasir), temulawak dan kencur (penambah nafsu makan), serta kucai sebagai obat pencahar. Penggunaan tertinggi adalah famili Zingiberaceae (4 species), habitus herba (43\%), bagian daun $(29 \%)$. Penggunaan terbanyak dengan cara diminum $(59 \%)$.

Keywords: Tumbuhan obat, gangguan sistem pencernaan, Dayak Iban, kabupaten Kapuas Hulu
\end{abstract}




\section{PENDAHULUAN}

Suku Dayak Iban adalah salah satu dari 158 sub suku Dayak yang ada di Kalimantan Barat (Alloy, 2008). Mereka tinggal dan tersebar di pedalaman kabupaten Kapuas Hulu yang merupakan wilayah terjauh dari ibukota Provinsi Kalimantan Barat. Budaya dan pengetahuan tradisional suku Dayak Iban masih tetap melekat dan terjaga hingga saat ini. Walaupun modernisasi sedikit banyak telah menggerus beberapa pengetahuan tradisi, mereka masih memiliki pengetahuan tentang penggunaan tumbuhan sebagai obat untuk mengatasi beragam penyakit yang diderita oleh komunitasnya. Dengan praktik tradisi kesehatan ini, masyarakat suku ini tetap memiliki hidup sehat sebagai salah satu unsur dalam Indeks Pembangunan Manusia (IPM).

Salah satu kelompok penyakit yang sering diderita oleh masyarakat adalah gangguan pada sistem pencernaan, yang dimulai dari mulut hingga bagian saluran pembuangan. Beberapa jenis penyakit yang termasuk dalam kelompok tersebut antara lain diare, sembelit, sakit perut, maag, konstipasi, sariawan, sakit di bagian mulut, keluarnya gas secara berlebihan, sakit gigi dan wasir (Tangjitman et al. 2015). Beberapa data menunjukkan bahwa gangguan pada sistem pencernaan merupakan suatu masalah yang serius dan perlu penanganan segera. Penyakit diare sebagai contoh memiliki prevalensi sebesar 3,5\% pada tahun 2013 dan menempati urutan ke 13 penyebab kematian di Indonesia (Balai Penelitian dan Pengembangan Kesehatan, 2013), dan sakit gigi (karies dan periodentitis) ditemukan pada hampir 95\% penduduk di dunia (Sepang, 2009).

Penelitian ini bertujuan untuk menganalisis pola pemanfaatan tumbuhan obat suku Dayak Iban di desa Lanjak Besar (dusun Tekalong dan Bejabang) dan Desa Sepandan (dusun Tematu 1 dan Tematu 3) Kabupaten Kapuas Hulu Kalimantan Barat terutama penggunaannya untuk mengatasi gangguan sistem pencernaan.

\section{METODOLOGI PENELITIAN}

Penelitian ini dilaksanakan di desa Lanjak Besar (dusun Tekalong dan Bejabang) dan Desa Sepandan (dusun Tematu 1 dan Tematu 3) Kecamatan Batang Lupar di Kabupaten Kapuas Hulu (Gambar 1). Penelitian ini dilakukan secara purposive sampling dengan teknik wawancara menggunakan kuisioner (daftar pertanyaan) yang telah dipersiapkan sebelumnya. Isi dari kuisioner tersebut antara lain jenis tumbuhan yang digunakan sebagai obat, bagian tumbuhan yang digunakan, cara meramu dan menggunakan, serta lokasi pengambilan tanaman. Informan yang menjadi target wawancara adalah masyarakat dari suku Dayak Iban di desa Lanjak Deras (dusun Tekalong dan Bejabang) dan Sepandan (Tematu 1 dan Tematu 3) yang mengetahui dan menggunakan tumbuhan sebagai bahan obat untuk mengatasi gangguan sistem pencernaan. $\mathrm{Di}$ dusun Tekalong terdapat $23 \mathrm{KK}$, dusun Bejabang $10 \mathrm{KK}$, dusun Tematu $135 \mathrm{KK}$ dan dusun Tematu $312 \mathrm{KK}$. Seluruh KK tersebut menjadi target wawancara (100\% responden).

Hasil wawancara kemudian dilakukan observasi di lapangan yaitu, dengan mengamati secara langsung setiap jenis tumbuhan yang diketahui berfungsi sebagai obat gangguan sistem pencernaan dan dilakukan pendokumentasian untuk kemudian dilakukan identifikasi tanaman hingga tingkat spesies. 


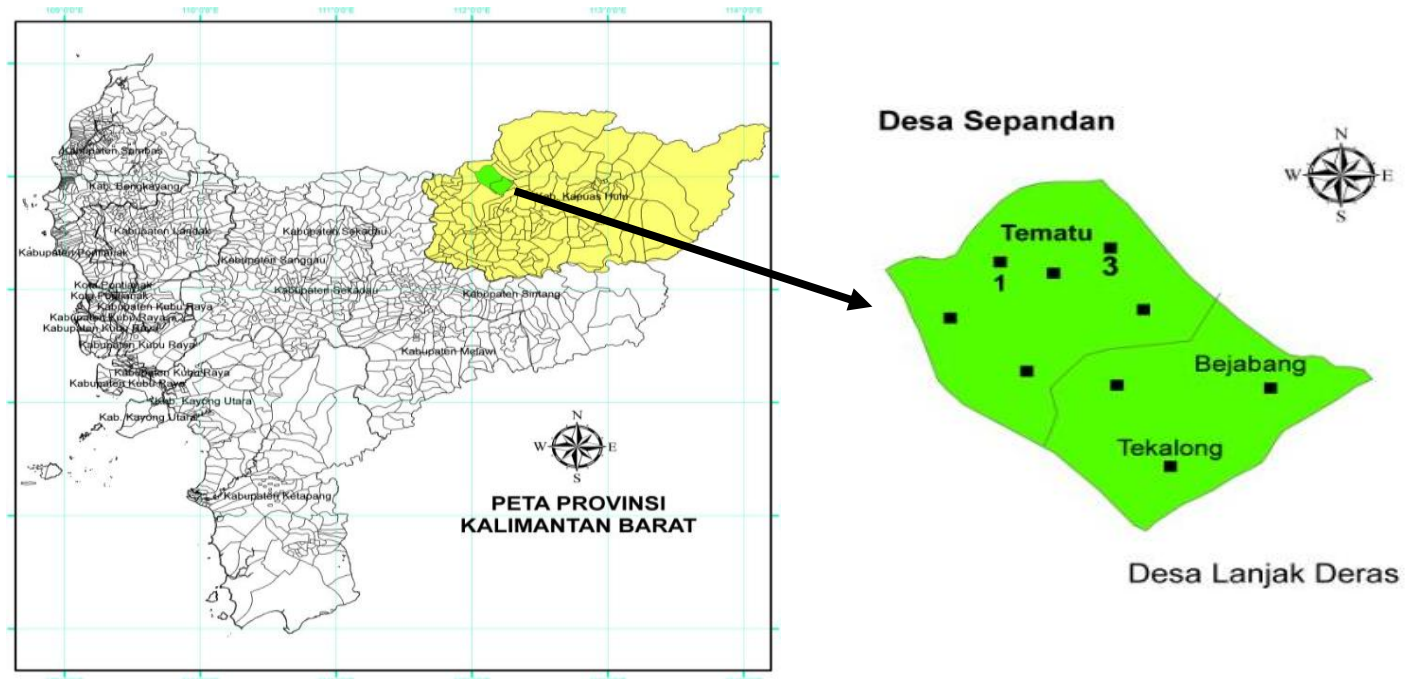

Gambar 1. Lokasi penelitian di Desa Lanjak Besar (dusun Tekalong dan Bejabang) dan Desa Sepandan (dusun Tematu 1 dan Tematu 3) kecamatan Batang Lupar Kabupaten Kapuas Hulu.

$\mathrm{UV}=\sum \mathrm{U} / \mathrm{n}$

UV = Nilai penggunaan

$\mathrm{U}=$ Jumlah laporan penggunaan

$\mathrm{n}=$ Jumlah total responden

$$
[\mathrm{CF}=(\mathrm{Nur}-\mathrm{Nt}) /(\mathrm{Nur}-1)
$$

$\mathrm{ICF}=$ Informant consensus factor

Nur = Jumlah laporan penggunaan untuk penyakit tertentu

$\mathrm{Nt}=$ Jumlah taxa atau tanaman yang digunakan untuk penyakit tertentu

$\mathrm{FL}(\%)=(\mathrm{Np} / \mathrm{N})+100$

$\mathrm{FL}=$ Fidelity level (\%)

$\mathrm{Np}=$ Jumlah laporan penggunaan spesies tertentu untuk penyakit tertentu

$\mathrm{N}=$ Jumlah total laporan penggunaan/ khasiat suatu tanaman
Data yang diperoleh berupa data tanaman dan pola pemanfaatannya (Use value/ UV, Informant concensus factorl ICF dan fidelity level $\mathrm{FL}$; mengacu pada Tangjitman et al. (2015)) untuk selanjutnya dilakukan analisis.

\section{HASIL DAN PEMBAHASAN}

Penggunaan tumbuhan obat oleh suku Dayak Iban untuk mengatasi beragam penyakit khususnya, yang terkait dengan masalah pencernaan, cukup beragam. Sebanyak 21 spesies tanaman obat telah digunakan oleh $60 \%$ responden, dan sebanyak $40 \%$ responden tidak mengetahui ataupun menggunakan tumbuhan obat untuk mengatasi masalah pencernaan. Adapun jenis-jenis tumbuhan obat yang digunakan secara jelas tertera pada Tabel 1. Jenis-jenis tanaman yang digunakan ini masih lebih rendah jika dibandingkan dengan hasil penelitian Tangjitman et al. (2015) di Karen, Thailand, dimana sekitar 36 jenis tumbuhan telah digunakan 
sebagai bahan pengobatan tradisional untuk mengatasi masalah pencernaan.

Jenis-jenis tanaman yang paling sering digunakan dan ditunjukkan dengan nilai penggunaan (use value/ UV) yang tinggi adalah bawang merah $(0,53)$, pisang $(0,5)$ dan jambu batu $(0,44)$. Tingginya nilai UV ketiga tanaman tersebut mengindikasikan bahwa level kepercayaan masyarakat untuk mengobati penyakit menggunakan tanaman obat tersebut cukup tinggi. Adapun penggunaannya secara spesifik antara lain bawang merah untuk mengatasi masuk angin, pisang untuk mengatasi sulit BAB dan jambu batu untuk diare. Seluruh responden yang menggunakan tanaman tersebut mengakui khasiat yang sama dari ketiga tanaman tersebut (khasiatnya tunggal). Tanaman obat yang memiliki nilai UV tinggi juga dapat menggambarkan kelimpahan dari jenis tanaman obat tersebut (Ayyanar dan Ignacimuthu, 2011). Hal ini memang ditunjukkan oleh hasil penelitian ini dimana bawang merah digunakan sebagai bumbu dapur utama di setiap keluarga, dan tanaman pisang dan jambu biji terdapat di hampir setiap pekarangan rumah warga.

Beberapa jenis tanaman seperti langsat $(0,36)$, jeruk sambal $(0,29)$, temulawak $(0,25)$, putri malu $(0,25)$ dan sirih $(0,24)$ menunjukkan nilai UV sedang, yang berarti level kepercayaan masyarakat terhadap kelima jenis ini dalam level intermediat. Jenis-jenis yang lain masuk kategori dengan level kepercayaan yang rendah karena termasuk jarang yang mengetahui ataupun menggunakan tumbuhan tersebut.

Jika dilihat dari fungsi atau khasiatnya, beberapa jenis tanaman hanya memiliki satu khasiat, terkecuali sirih, buan dan jahe yang memiliki lebih dari satu khasiat. Hasil penelitian ini sangat menarik karena terdapat keseragaman pengetahuan di antara masyarakat terutama mengenai khasiat tanaman walaupun mereka tinggal di lokasi yang berbeda (Dua desa dan empat dusun yang berbeda).

Tabel 1 menunjukkan pola pemanfaatan tumbuhan obat oleh suku Dayak Iban untuk mengatasi masalah atau gangguan pencernaan.

\section{Famili}

Jenis-jenis tumbuhan obat yang digunakan oleh suku Dayak Iban untuk mengatasi masalah pencernaan terdiri dari 14 famili tanaman. Famili Zingiberaceae adalah yang tertinggi dengan 4 species, diikuti Amaryllidaceae, Fabaceae, Myrtaceae dan Piperaceae yang masing-masing dengan 2 spesies. Beberapa famili yang lain hanya terdiri dari 1 spesies, yang secara lengkap dapat dilihat pada Gambar 2.

Famili Zingiberaceae juga menjadi bagian penting dari pengobatan terhadap gangguan sistem pencernaan di Karen, Thailand (Tangjitman et al., 2015) dan di Desa Keseneng Jawa Tengah (Arum et al., 2012). Tanaman jahe ( $Z$. officinale) yang merupakan bagian dari famili Zingiberaceae digunakan oleh suku Dayak Iban untuk mengatasi sering buang angin (flatulence). Beberapa hasil studi menunjukkan bahwa famili ini mengandung minyak atsiri berupa gingerol yang memiliki kemampuan untuk menghambat multiplikasi bakteri di usus yang melakukan fermentasi terhadap karbohidrat sehingga berdampak pada terhambatnya proses pencernaan yang pada akhirnya timbul sering buang angin (Tangjitman et al., 2015). 


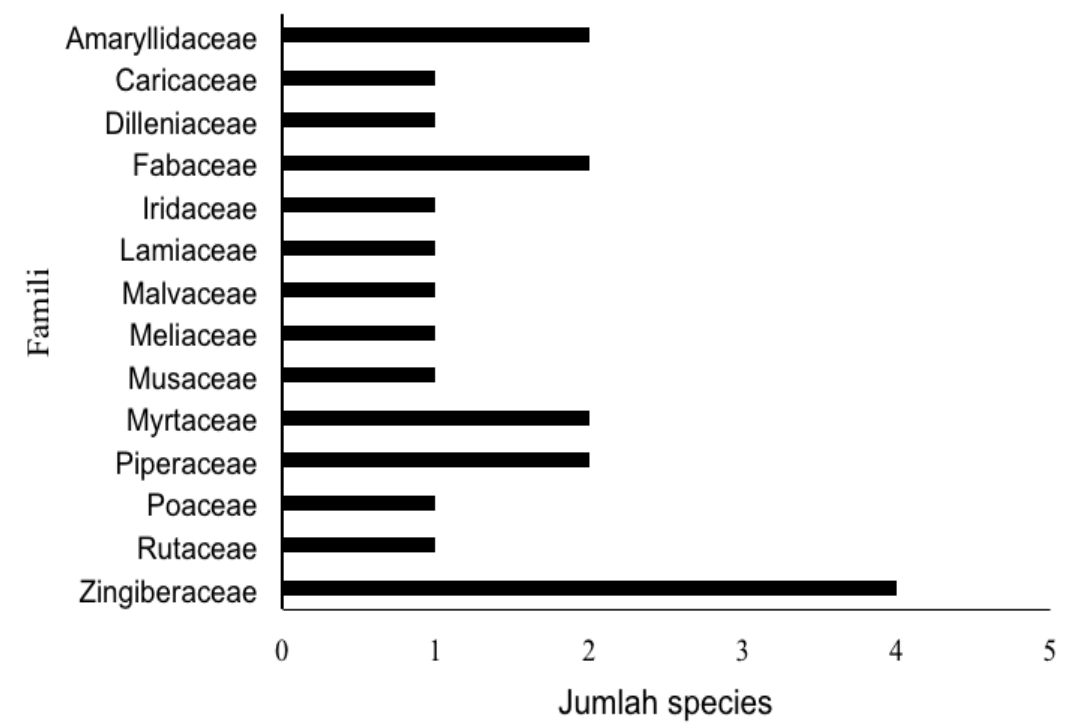

Gambar 2. Famili tanaman obat yang digunakan oleh suku Dayak Iban

2. Habitus dan bagian tanaman

Bentuk tanaman atau habitus yang digunakan oleh suku Dayak Iban sebagai bahan pengobatan untuk masalah pencernaan cukup beragam. Kelompok herba adalah yang tertinggi (43\%), diikuti oleh pohon (24\%), perdu $(19 \%)$, liana $(9 \%)$, dan semak $(5 \%)$ yang secara jelas tertera pada Gambar 3A. Herba merupakan kelompok tanaman berbatang basah yang umumnya merupakan tanaman budidaya seperti famili Zingiberaceae.

Tanaman herba memiliki pertumbuhan yang cepat dan mudah ditanam di sekitar rumah ataupun pekarangan sehingga keberadaannya menjadi sangat penting sebagai bagian dari tanaman obat keluarga (TOGA) serta meminimalisir kerusakan hutan akibat eksploitasi yang berlebihan terhadap tumbuhan obat (Mussarat et al., 2014; Tugume et al., 2016).

Bagian tanaman yang paling dominan digunakan sebagai bahan obat adalah daun (29\%), buah (25\%) dan rimpang (17\%). Beberapa bagian tanaman yang lain seperti akar, umbi, kulit buah dan kulit kayu secara persentase tidaklah besar, berkisar antara $4-9 \%$ saja, yang secara jelas dapat dilihat pada Gambar 3B. Hasil yang sama terutama penggunaan daun sebagai bagian tumbuhan obat tertinggi yang digunakan dalam proses pengobatan antara lain ditunjukkan oleh Zuhud et al. (2008) dan Yusro et al. $\left(2013^{\mathrm{a}, \mathrm{b}}\right)$. Penggunaan daun yang tinggi dalam proses pengobatan tradisional diduga karena bagian ini mudah diperoleh dan mudah dalam proses meramunya jika dibandingkan dengan bagian tanaman yang lain (Hamzari 2008, Setyowati 2010, Samoisy dan Mahoomodoodally, 2015). Secara konservasi, adanya regenerasi daun yang cepat berdampak pada ketidak khawatiran akan hilangnya kelestarian tumbuhan walaupun digunakan dalam skala yang besar (Setyowati 2010). 
Tabel 1. Jenis-jenis tumbuhan obat untuk mengatasi masalah percernaan yang digunakan suku Dayak Iban

\begin{tabular}{|c|c|c|c|c|c|c|}
\hline No. & Nama lokal & Nama latin & Famili & Habitus & Kegunaan & $\begin{array}{c}\text { Bagian yang } \\
\text { digunakan }\end{array}$ \\
\hline 1 & Jambu batu & Psidium guajava var pyrifera & Myrtaceae & Perdu & Diare & Daun \\
\hline 2 & Salam & Syzygium poliantum & Myrtaceae & Pohon & Diare & Daun \\
\hline 3 & Buan & Dillenia suffruticosa & Dilleniaceae & Pohon & Diare, sakit lidah (berwarna putih) & Daun, buah \\
\hline 4 & Jahe & Zingiber officinale & Zingiberaceae & Herba & Sering buang angin, sakit perut, masuk angin & Rimpang \\
\hline 5 & Leban & Vitex pubescens & Lamiaceae & Pohon & Maag & Akar, buah \\
\hline 6 & Jeruk sambal & Citrus amblycarpa & Rutaceae & Perdu & Sariawan & Buah \\
\hline 7 & Pisang & Musa acuminata & Musaceae & Herba & Sulit BAB & Buah \\
\hline 8 & Bawang merah & Allium cepa & Amaryllidaceae & Herba & Masuk angina & Umbi \\
\hline 9 & Sirih & Piper betle & Piperaceae & Liana & Sakit gigi, sakit lidah (berwarna putih) & Daun \\
\hline 10 & Japa & Zingiber casumounar & Zingiberaceae & Herba & Penambah nafsu makan & Rimpang \\
\hline 11 & Temulawak & Curcuma zanthorrhiza & Zingiberaceae & Herba & Penambah nafsu makan & Rimpang \\
\hline 12 & Kencur & Kaempferia galanga & Zingiberaceae & Herba & Penambah nafsu makan & Rimpang \\
\hline 13 & Pepaya & Carica papaya & Caricaceae & Perdu & Sulit BAB & Buah \\
\hline 14 & Langsat & Lansium domesticum & Meliaceae & Pohon & Maag & Kulit kayu, kulit buah \\
\hline 15 & Sahang putih & Piper ningrum & Piperaceae & Liana & Sakit perut & Buah \\
\hline 16 & Sugan & Cassia alata & Fabaceae & Perdu & Sakit perut & Akar \\
\hline 17 & Putri malu & Mimosa pudica & Fabaceae & Semak & Sakit gigi & Daun \\
\hline 18 & Kucai & Allium tuberosum & Amaryllidaceae & Herba & Pencahar & Daun \\
\hline 19 & Durian & Durio zibethinus & Malvaceae & Pohon & Sakit lidah (berwarna putih) & Kulit buah \\
\hline 20 & Bawang Lembak & Eleutherine bulbosa & Iridaceae & Herba & Wasir & Umbi \\
\hline 21 & Rumput cupak & Imperata cylindrica & Poaceae & Herba & Sakit perut & Daun \\
\hline
\end{tabular}


Lanjutan Tabel 1.

\begin{tabular}{|c|c|c|c|c|c|c|c|}
\hline No. & Cara pengolahan & $\begin{array}{c}\text { Cara } \\
\text { menggunakan }\end{array}$ & $\begin{array}{c}\text { Sumber } \\
\text { tanaman }\end{array}$ & $\begin{array}{c}\text { Status } \\
\text { tanaman }\end{array}$ & $\begin{array}{c}\text { Bentuk } \\
\text { Pemakaian } \\
\end{array}$ & $\Sigma \mathbf{U}$ & $\begin{array}{l}\text { Use value } \\
\text { (UV) }\end{array}$ \\
\hline 1 & Rebus & Minum & Pekarangan & Budidaya & Tunggal & 35 & 0,44 \\
\hline 2 & Rebus & Minum & Pekarangan & Budidaya & Tunggal & 7 & 0,09 \\
\hline 3 & Bakar, asap, parut & Tempel & Hutan & Liar & Tunggal, campuran & 15 & 0,19 \\
\hline 4 & Rebus, tumbuk & Minum & Pekarangan & Budidaya & Tunggal, campuran & 13 & 0,16 \\
\hline 5 & Rebus, tanpa pengolahan & Minum & Hutan & Liar & Tunggal & 11 & 0,14 \\
\hline 6 & Peras & Minum & Pekarangan & Budidaya & Campuran & 23 & 0,29 \\
\hline 7 & Tanpa pengolahan & Makan & Pekarangan & Budidaya & Tunggal & 40 & 0,50 \\
\hline 8 & Parut & Minum, tempel & Pasar & Beli & Tunggal & 42 & 0,53 \\
\hline 9 & Kunyah & Minum & Pekarangan & Budidaya & Tunggal & 19 & 0,24 \\
\hline 10 & Parut & Tempel & Pekarangan & Budidaya & Tunggal & 11 & 0,14 \\
\hline 11 & Rebus, parut & Minum & Pekarangan & Budidaya & Tunggal & 20 & 0,25 \\
\hline 12 & Rebus, parut & Minum & Pekarangan & Budidaya & Tunggal & 4 & 0,05 \\
\hline 13 & Tanpa pengolahan & Makan & Pekarangan & Budidaya & Tunggal & 2 & 0,03 \\
\hline 14 & Rebus & Minum & Hutan & Liar & Tunggal & 29 & 0,36 \\
\hline 15 & Tanpa pengolahan & Tempel & Pekarangan & Budidaya & Tunggal & 6 & 0,08 \\
\hline 16 & Rebus & Minum & Hutan & Liar & Tunggal & 12 & 0,15 \\
\hline 17 & Tumbuk & Tempel & Pekarangan & Liar & Tunggal & 20 & 0.25 \\
\hline 18 & Rebus & Minum & Pekarangan & Budidaya & Tunggal & 9 & 0,11 \\
\hline 19 & Tanpa pengolahan & Tempel & Pekarangan & Budidaya & Tunggal & 15 & 0,19 \\
\hline 20 & Rebus & Minum & Pekarangan & Budidaya & Campuran & 9 & 0,11 \\
\hline 21 & Tumbuk & Tempel & Pekarangan & Liar & Tunggal & 1 & 0,01 \\
\hline
\end{tabular}




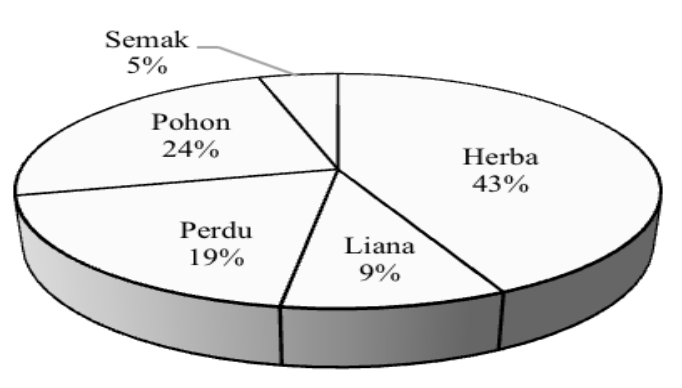

A

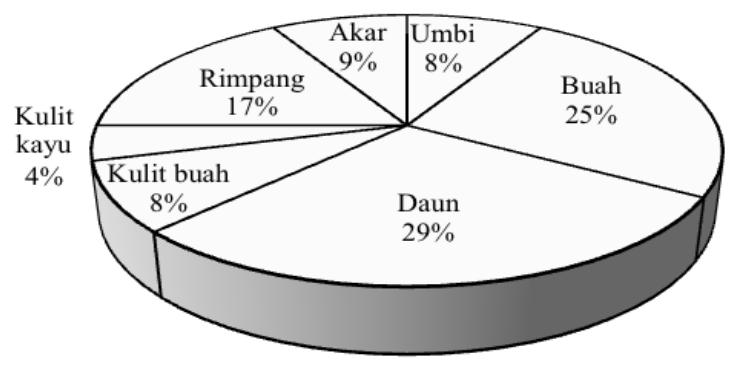

B

Gambar 3. Habitus (A) dan bagian tanaman obat (B) yang digunakan oleh suku Dayak lban

3. Cara pengolahan dan penggunaannya

Teknik pengolahan atau proses meramu tanaman sebelum digunakan oleh masyarakat suku Dayak Iban cukup beragam, antara lain dengan cara direbus, diparut, ditumbuk, dikunyah, diasapi, dibakar, diperas ataupun tanpa pengolahan. Cara yang paling banyak dan paling mudah dilakukan adalah direbus (37\%), diparut dan tanpa pengolahan yang masing-masing secara persentase sama yaitu $18 \%$. Adapun cara yang lain berkisar antara $4-11 \%$, yang secara lengkap tertera pada Gambar $4 \mathrm{~A}$.

Pengolahan tertinggi dengan cara direbus juga ditunjukkan oleh hasil penelitian Mirdeilami et al. (2011), Johnsy et al. (2013), dan Yusro et al. $\left(2013^{\mathrm{a}, \mathrm{b}}\right)$. Proses ekstraksi dalam hal ini dengan teknik direbus mempergunakan pelarut air merupakan cara tradisional masyarakat dalam mempersiapkan ramuan, yang diduga secara efektifitas dalam mengeluarkan zat aktif yang terkandung dalam tanaman lebih cepat jika dibandingkan dengan cara yang lain (Nunkoo dan Mahomodally, 2012). Proses meramu tanaman menjadi bahan yang siap digunakan akan selaras dengan cara menggunakan ramuan tersebut. Misalnya, dengan cara rebus merupakan indikasi awal yang menunjukkan bahwa ramuan tersebut digunakan dengan cara diminum ataupun ditumbuk yang cara menggunakannya dengan cara ditempel. Hasil penelitian ini menunjukkan bahwa minum merupakan cara menggunakan yang tertinggi, diikuti dengan ditempel dan dimakan, yang secara lengkap tersaji pada Gambar 4B. Hasil penelitian ini selaras dengan hasil penelitian yang dilakukan oleh Khan et al. (2014) di distrik Hangu, Pakistan dimana minum adalah cara tertinggi dalam menggunakan ramuan tumbuhan obat untuk mengatasi masalah percernaan. Cara pengobatan tertinggi dengan meminum ramuan juga dilakukan oleh suku Dayak yang lain di Kalimantan Barat seperti suku Dayak Kanayan, Daro dan Bukat (Yusro et al., 2013 ${ }^{\mathrm{b}}$, Yusro et al., $2014^{\mathrm{b}}$ ). 


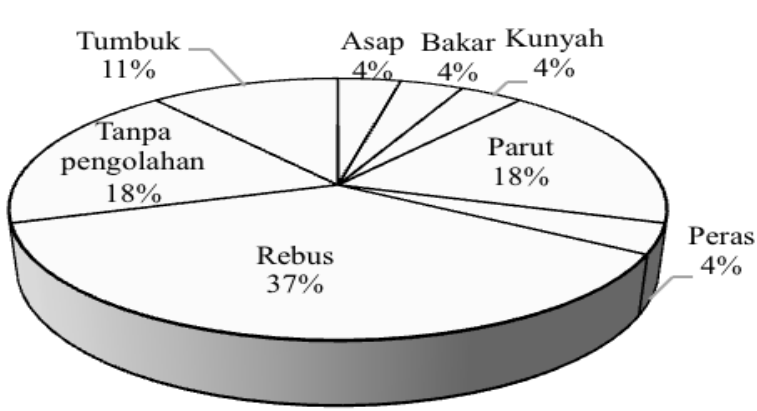

A

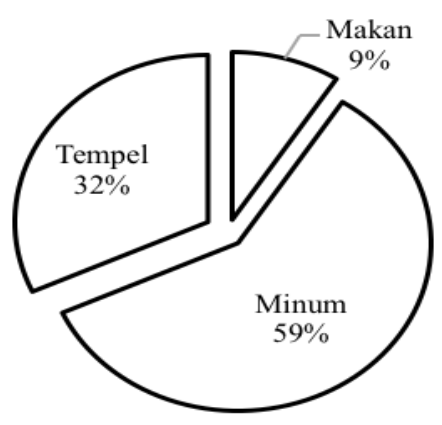

B

Gambar 4. Cara mengolah (A) dan menggunakan tanaman obat (B) yang dipraktikkan oleh suku Dayak Iban

Diduga bahwa dengan proses meminum ramuan, efektivitas dan aktivitasnya dalam mengobati penyakit jauh lebih cepat dan lebih baik jika dibandingkan dengan cara ditempel ataupun cara yang lain, walaupun hal ini terkadang disesuaikan dengan kondisi penyakit yang diderita seseorang.

\section{Sumber dan status tanaman} Jenis-jenis tanaman yang digunakan dominannya termasuk ke dalam tanaman budidaya, sehingga keberadaan atau sumber diperolehnya tanaman berasal dari lingkungan sekitar seperti pekarangan atau kebun $(76 \%)$ (Gambar 5A). Selain itu, beberapa jenis tanaman harus diperoleh dari hutan dikarenakan keberadaanya yang tumbuh secara liar di hutan (19\%), dan sebagian lagi tidak dibudidayakan ataupun keberadaannya tidak ada di hutan sehingga harus dibeli di pasar ataupun warung (5\%) oleh masyarakat jika ingin menggunakannya seperti tanaman bawang merah.

Walaupun suku Dayak Iban telah menunjukkan upaya pembudidayaan tanaman obat dengan cara menanam di pekarangan, mereka masih menggunakan tanaman obat yang berasal dari hutan. Hasil penelitian ini selaras dengan penelitian Kunwar et al. (2015) yang dilakukan di Nepal dimana hutan sekunder merupakan salah satu lokasi tempat tumbuh tanaman obat selain pekarangan rumah.

Jenis tanaman yang digunakan sebagai bahan untuk membuat ramuan dalam mengatasi masalah pencernaan berasal dari tanaman budidaya ( 67 . Sisanya sebanyak $28 \%$ tumbuh secara liar dan ataupun dibeli (5\%) dari pasar/warung (Gambar 5B).

Pembudidayaan tanaman ini sangat menunjang dalam upaya pencegahan dini suatu penyakit karena sumber tanaman yang berada di sekitar akan memudahkan untuk diambil dan proses penanganan terhadap penyakit yang diderita oleh anggota keluarga akan lebih cepat. Selain itu, jenis-jenis tumbuhan yang digunakan sebagai obat juga berfungsi sebagai bahan pangan terutama sebagai bumbu dapur. 


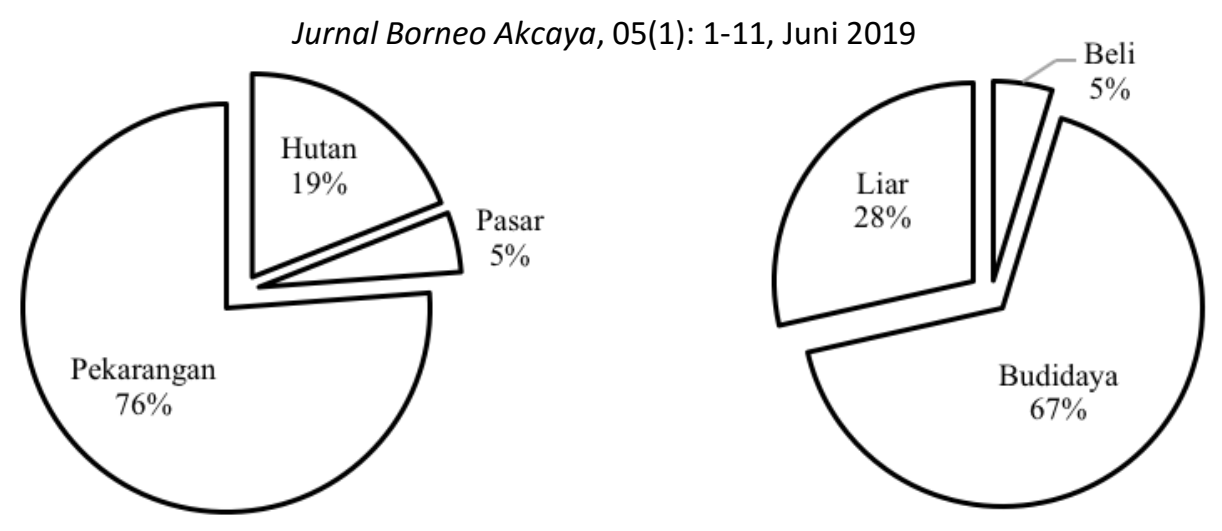

Gambar 5. Sumber (A) dan status tanaman obat (B) yang digunakan oleh suku Dayak Iban

Pemerintah saat ini sedang menggalakkan program gizi dan obat keluarga (GIOK). Dengan demikian, adanya penggunaan tanaman yang berstatus tanaman budidaya secara tidak langsung akan berdampak pada peningkatan gizi dan kesehatan keluarga. Usaha pembudidayaan tanaman obat yang liar untuk ditanam sebagai tanaman pekarangan merupakan salah satu bentuk usaha untuk menggabungkan manajemen lingkungan dan keberagaam kebudayaan. Melalui usaha ini, diharapkan ketahanan pangan dan kesehatan keluarga dapat ditingkatkan, dan secara tidak langsung dapat membuka peluang peningkatan pendapatan keluarga serta konservasi sumberdaya alam. Usaha yang sama juga dilaporkan oleh Karhagomba et al. (2013) di Buhozi, Kongo.

5. Bentuk pemakaian

Dalam proses meramu tumbuhan obat, masyarakat Dayak Iban dominannya menggunakannya secara tunggal (83\%), dan sebagian lagi secara campuran (17\%) (Gambar 6). Hasil ini selaras dengan beberapa penelitian sebelumnya yang dilakukan terhadap beberapa sub suku Dayak di Kalimantan Barat (Yusro et al., $2013^{\mathrm{a}, \mathrm{b}}$, Yusro et al., 2014 ${ }^{\mathrm{a}, \mathrm{b}}$ ).

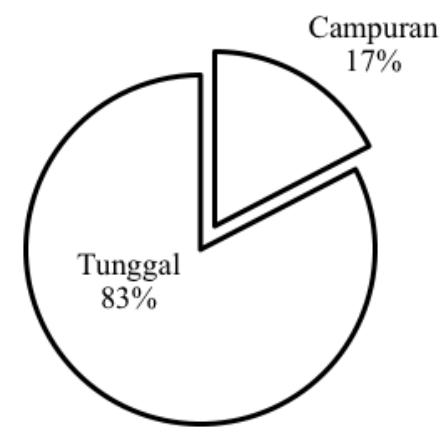

Gambar 6. Bentuk pemakaian tanaman obat yang digunakan oleh suku Dayak Iban 
Responden yang menjadi target dalam penelitian ini adalah masyarakat umum, bukan dukun ataupun pengobat tradisional. Pengetahuan yang dimiliki oleh responden dalam meramu tumbuhan menjadi bahan obat sangat sederhana (penggunaan tanaman secara tunggal). Oleh karena itu, efektifitas dalam mengobati suatu penyakit agak lebih lama proses penyembuhannya. Hal ini tentu berbeda dengan dukun yang umumnya menggunakan beberapa jenis campuran tanaman untuk membuat satu ramuan untuk mengobati suatu penyakit.

Nilai informan konsensus faktor (ICF) yang diperoleh dari hasil penelitian ini sangat bervariasi, mulai dari 0 sampai dengan 1 . Nilai tertinggi dari ICF $(0,85-1,00)$ mengindikasikan level terbaik kesepakatan atau kesepahaman dari informan dalam hal penggunaan atau khasiat dari tumbuhan obat yang digunakan (Tangjitman et al., 2015) untuk mengatasi beragam masalah/ gangguan sistem pencernaan, seperti maag $(1,00)$, sariawan $(1,00)$, pencahar $(1,00)$, susah buang air besar $(9,98)$, dan masuk angin $(0,98)$. Nilai ICF dari setiap kategori penyakit dapat dilihat pada Tabel 2. Menurut Gazzaneo et al. (2005); Khan et al. (2012) dan Tangjitman et al. (2015), nilai ICF yang tinggi sangat penting dalam hal identifikasi tanaman yang potensial sebagai obat, terutama untuk penulusuran senyawa bioaktifnya.

Hasil penelitian ini melaporkan bahwa jenis tanaman yang memiliki nilai fidelity level (FL) tertinggi adalah salam (100) untuk mengatasi diare, langsat (100) untuk flatulance, leban (100) untuk maag, jeruk sambal (100) untuk sariawan, durian (100) untuk sakit lidah, pisang (100) dan papaya (100) untuk susah buang air besar, sahang putih (100), sugan (100) dan rumput cupak (100) untuk sakit perut, bawang merah (100) untuk masuk angin, putri malu (100) untuk sakit gigi, japa (100) dan bawang lembak (100) untuk ambein atau wasir, temulawak (100) dan kencur (100) untuk penambah nafsu makan, serta kucai (100) sebagai obat pencahar.

Tabel 2. Kategori penyakit/gangguan masalah pencernaan dan informan konsensus faktor (informant concensus factor, ICF).

\begin{tabular}{rlccc}
\hline No. & \multicolumn{1}{c}{ Kategori Penyakit } & $\begin{array}{c}\text { Jumlah Penggunaan } \\
\text { (Nr) }\end{array}$ & $\begin{array}{c}\text { Jumlah Tanaman } \\
\text { (Nt) }\end{array}$ & ICF \\
\hline 1 & Diare & 56 & 4 & 0,95 \\
2 & Sering buang angin (flatulance) & 38 & 2 & 0,97 \\
3 & Maag & 11 & 1 & 1,00 \\
4 & Sariawan & 23 & 1 & 1,00 \\
5 & Sakit lidah (bercak putih) & 37 & 3 & 0,94 \\
6 & Susah buang air besar & 42 & 2 & 0,98 \\
7 & Sakit perut & 27 & 5 & 0,85 \\
8 & Keracunan makanan & 0 & 0 & 0,00 \\
9 & Masuk angin (mual, pusing, muntah) & 46 & 2 & 0,98 \\
10 & Sakit gigi & 25 & 2 & 0,96 \\
11 & Ambein/wasir & 20 & 2 & 0,95 \\
12 & Nafsu makan & 23 & 2 & 0,95 \\
13 & Pencahar & 10 & 1 & 1,00 \\
\hline
\end{tabular}


Tabel 3. Nilai fidelity level (FL) untuk jenis-jenis tanaman yang digunakan oleh suku Dayak Iban

\begin{tabular}{|c|c|c|}
\hline No. & Kategori Penyakit & Jenis Tanaman \\
\hline 1 & Diare & $\begin{array}{l}\text { Jambu batu }(94,12) \text {, salam }(100) \text {, buan }(44,44) \text {, } \\
\text { jahe }(29,93)\end{array}$ \\
\hline 2 & Sering buang angin (flatulance) & Jahe $(33,33)$, langsat $(100)$ \\
\hline 3 & Maag & Leban (100) \\
\hline 4 & Sariawan & Jeruk sambal (100) \\
\hline 5 & Sakit lidah (bercak putih) & Buan $(55,56)$, sirih $(66,67)$, durian $(100)$ \\
\hline 6 & Susah buang air besar & Pisang (100), pepaya (100) \\
\hline 7 & Sakit perut & $\begin{array}{l}\text { Jahe }(29,93) \text {, sirih }(5,56) \text {, sahang putih }(100) \text {, } \\
\text { sugan }(100) \text {, rumput cupak }(100)\end{array}$ \\
\hline 8 & Keracunan makanan & Tidak ada yang mengetahui \\
\hline 9 & Masuk angin (mual, pusing, muntah) & Jahe $(14,81)$, bawang merah $(100)$ \\
\hline 10 & Sakit gigi & Sirih $(27,78)$, putri malu $(100)$ \\
\hline 11 & Ambein/wasir & Japa (100), bawang lembak (100) \\
\hline 12 & Nafsu makan & Temulawak (100), kencur (100) \\
\hline 13 & Pencahar & Kucai (100) \\
\hline
\end{tabular}

Tumbuhan obat yang digunakan ini menjadi petunjuk potensial dari jenisjenis tanaman yang memiliki khasiat penyembuhan yang tinggi terkait dengan penyakit tertentu. Khan et al. (2012) mengemukakan bahwa tanaman yang memiliki FL tertinggi cenderung popular di antara komunitas masyarakat dalam mengobati suatu penyakit tertentu. Hal ini berarti tanaman tersebut memiliki kemampuan yang tinggi dalam mengobati penyakit tertentu. Tanaman yang memiliki nilai FL tertinggi dapat menjadi target lebih lanjut terutama identifikasi terhadap senyawa bioaktifnya yang bertanggung jawab terhadap penyembuhan dari suatu penyakit tertentu (Tangjitman et al., 2015).

\section{KESIMPULAN}

Ada 21 spesies tanaman obat yang telah digunakan oleh $60 \%$ responden untuk mengatasi masalah pencernaan, dan spesies dengan penggunaan tertinggi (UV). Spesis tanaman obat ini meliputi bawang merah $(0,53)$, pisang $(0,5)$ dan jambu batu $(0,44)$. Kelompok penyakit yang memiliki nilai ICF tertinggi adalah maag $(1,00)$, sariawan $(1,00)$, pencahar $(1,00)$, susah buang air besar $(9,98)$, dan masuk angin $(0,98)$. Jenis-jenis tanaman yang memiliki nilai fidelity level (FL) tertinggi (100) adalah salam untuk mengatasi diare, langsat untuk flatulance, leban untuk maag, jeruk sambal untuk sariawan, durian untuk sakit lidah, pisang dan papaya untuk susah buang air besar, sahang putih, sugan dan rumput cupak untuk sakit perut, bawang merah untuk masuk angin, putri malu untuk sakit gigi, japa dan bawang lembak untuk ambein atau wasir, temulawak dan kencur untuk penambah nafsu makan, serta kucai sebagai obat pencahar. Penggunaan tertinggi tumbuhan obat adalah pada famili Zingiberaceae (4 species), habitus herba (43\%), bagian daun (29\%), dan dengan cara diminum (59\%).

\section{REKOMENDASI}

Perlu penelitian lanjutan untuk mengatahui bioaktivitas dan efektivitas dari jenis-jenis tanaman yang digunakan oleh suku Dayak Iban dalam mengatasi masalah ataupun gangguan sistem pencernaan. Selain itu, jenis-jenis tanaman dengan nilai 
UV dan FL tertinggi berpotensi untuk digunakan oleh masyarakat di wilayah yang lain terkait fungsinya dalam mengatasi gangguan sistem pencernaan. Dalam upaya melestarikan kearifan lokal terkait pengobatan untuk mengobati penyakit masyarakat direkomendasikan kepada Pemerintah Provinsi Kalimantan Barat, khususnya Dinas Kesehatan Provinsi dan Pemerintah Kabupaten Kapuas Hulu untuk melakukan pendokumentasian tanaman obat.

\section{UCAPAN TERIMA KASIH}

Terima kasih penulis ucapkan kepada Fakultas Kehutanan Untan yang telah membiayai penelitian ini melalui dana DIPA dengan surat perjanjian kontrak no. 558/UN22.7/PP/2018.

\section{DAFTAR PUSTAKA}

Abera B. 2014. Medicinal plants used in traditional medicine by Oromo people, Ghimbi District, Southwest Ethiophia. Journal of Ethnobiology and Ethnomedicine, 10 (40): 1-15.

Albuquerque U.P., Soldati G.T., Sieber S.S., Ramos M.A., Sa J.C., dan Souza L.C. 2011. The use of plants in the medical system of the fulni-o people (NE Brazil): a perspective on age and gender. Journal of Ethnopharmacology. 133: 866-873.

Alloy S, Albertus, Yovinus dan Istiyani CP. 2008. Peta keberagaman subsuku Dayak di Kalimantan Barat. Dayakologi Institute. Pontianak.

Almeida C.F.C.B.R, Ramos M.A., Amorin A.L.C., dan Albuquerque. 2010. A comparison of knowledge about medicinal plants for three rural communities in the semi-arid region of northeast of Brazil. Journal of Ethnipharmacology. 127: 674-684.

Amsalu N, Bezie $Y$, Fentahun $M$, Alemayehu A dan Amsalu G. 2018. Use and conservation of medicinal plants by indigenous people of Gozamin Wereda, East Gojjam zone of Amhara region, Ethiopia: An ethnobtanical approach. Evid. Based Complementary Altern. Med., 2018: 1-23.

Arum GP, Retnoningsih A dan Irsadi A. 2012. Etnobotani Tumbuhan Obat Masyarakat Desa Keseneng Kecamatan Sumowono Kabupaten Semarang Jawa Tengah. Unnes J. Life Sci, 1 (2): 1-7.

Ayyanar, M. and Ignacimuthu, S. 2011. Ethnobotanical survey of medicinal plants commonly used by Kani tribals in Tirunelveli hills of Western Ghats, India. J. Ethnopharmacol. 134: 851-864.

Balai Penelitian dan Pengembangan Kesehatan (ed.). 2013. "Riset kesehatan dasar 2013", Kementerian Kesehatan RI, Jakarta.

Gazzaneo L., de Lucena R., de Albuquerque U. 2005. Knowledge and use of medicinal plants by local specialist in an region of Atlantic forest in the state of Pernambuco (Notheastern Brazil). J Etnobiol Ethnomed. 1 (9): 1-8

Hamzari. 2008. Identifikasi tanaman obat-obatan yang dimanfaatkan oleh masyarakat sekitar hutan Tabo-Tabo. Jurnal Hutan dan Masyarakat III (2) :111-234.

Jabbar A., Musdalipah dan Nurwanti A. 2016. Studi pengetahuan, sikap dan tindakan terhadap penggunaan obat tradisional bagi 
masyarakat di Desa Sabi-sabila Kecamatan Mowene Kabupaten Kolaka Timur. Majalah farmasi, sains dan kesehatan. 3 (1): 1922.

Johnsy G, Beena S. dan Kaviyarasan V. 2013. Ethno botanical survey of medicinal plants used for the treatment of diarrhea and dysentery. International Journal of Medicine and Medical Sciences. 3(1) : 332-338.

Kadir MF., Sayeed MS dan Mia MMK. 2012. Ethnopharmacological survey of medicinal plants used by indigenous and tribal people in Rangamati, Bangladesh. J. Ethnopharmacol, 144: 627-637.

Khan I, Abdelsalam NM, Fouad $H$, Tariq A, Ullah $\mathrm{R}$ dan Adnan $\mathrm{M}$. $2014 . \quad$ Application of ethnobotanical indices on the use of traditional medicines against common diseases. Evid. Based Complementary Altern. Med., 2014: 1-22.

Karhagomba IB, Mirindi A, Mushagalusa TB, Nabino VB, Koh $\mathrm{K}$ dan Kim HS. 2013. The cultivation of wild food and medicinal plants for improving community livelihood: The case of Buhozi site, DR Congo. Nut Res Pract. 7 (6): 510-518.

Kunwar, RM., Acharya R.P., Chowdhary, C.L. dan Bussmann, R.W. 2015. Medicinal plants dynamics in indigenous medicines in Farwest Nepal. J. Ethnopharmacol., 163: 210-219.

Mafimisebi T., Oguntade A.E., Fajemisin A.N., and Aiyelari O.P. 2012. Local knowledge and socio-economic determinants of tradisional medicines utilization in livestock health management in Southwest Nigeria. Journal of Ethnobiology and Ethnomedicine, 8 (2): 1-9.
Mirdeilami SZ, Barani H, Mazandarani M, dan Heshmati GA. 2011. Ethnopharmacological Survey of Medicinal Plants in Maraveh Tappeh Region, North of Iran. Iranian Journal of Plant Physiology 2(1): 327-338.

Nunkoo, D.M. and Mahomoodally. M.F. 2012.

Ethnopharmacological survey of native remedies commonly used against infectious diseases in tropical island of Mauritius. J. Ethnopharmacol., 143: 548-564.

Samoisy, A.K. and Mahomoodally, M.F. 2015.

Ethnopharmacological analysis of medicinal plants used against non- communicable diseases in Rodrigues Island, Indian Ocean. J. Ethnopharmacol., 173: 20-38.

Setyowati F.M. 2010. Etnofarmakologi dan pemakaian tanaman obat suku Dayak Tunjung di Kalimantan Timur. Media Litbang Kesehatan XX (3): 104-112.

Shah, S.A., Shah, N.A., Ullah, S., Alam, M.M., Badsah, H., Ullah, S. and Mumtaz, A.S. 2016. Documenting the indigenous knowledge on medicinal flora from communities residing near Swat River (Suvastu) and in high mountainous areas in SwatPakistan. J. Ethnopharmacol., 182: 67-79.

Silva FS, Ramos MA, Hanazaki N dan Albuquerque UP. 2011. Dynamics of traditional knowledge of medicinal plants in a rural community in the Brazilian semi-arid region. Braz. J. Pharmacogn, 21 (3): 382-391.

Tangjitman K., Wongsawad C., Kamwong K., Sukkho $T$ dan Trisonthi C. 2015. Ethnomedical plants used for digestive system disorders by the Karen of Nothern Thailand. Journal of Ethnobiology 
and Ethnomedicine, 11 (27): 1 13.

Tugume, P., Kakudidi, E.K., Buyinza, M., Namaalwa, J., Kamatenesi, M., Mucunguzi, P. and Kalema, 2016. Ethnobotanical survey of medicinal plant species used by communities around Mabira Central Forest Reserve, Uganda. J. Ethnobiol. Ethnomed., 12:1-28.

Yusro F., Diba F., Mariani Y., Etis E.P., Leonardo dan Randi A. $2013^{a}$. "Ragam jenis tumbuhan obat di Kalimantan Barat, Jilid I". FU Press. Pontianak.

Yusro F., Diba F., Mariani Y., dan Ohtani K. 2013 ${ }^{\mathrm{b}}$. Medicinal plants utilization of Dayak Kanayant ethnic in sungai enau village, Kubu Raya regency. Foresta, 2: 23-29.

Yusro F., Diba F., Mariani Y., Mulyadi dan Astria. 2014". "Ragam jenis tumbuhan obat di Kalimantan Barat, Jilid II", FU Press. Pontianak.

Yusro F., Mariani Y., Diba F., dan Ohtani K. 2014 ${ }^{\mathrm{b}}$. Inventory of medicinal plants for fever used by four Dayak subethnic in West Kalimantan province Indonesia. Kuroshio Science, 8:33-38. 